\title{
MInstitute"mk
}

\section{BOOK REVIEW: Malaya 1941}

Dazmin Daud (Corresponding author)

E-mail: dazmindaud@ucsiuniversity.edu.my

Received: August 27, 2020 Accepted: October 3, 2020 Published: October 18, 2020

doi:10.5296/ijch.v7i2.17802 URL: https://doi.org/10.5296/ijch.v7i2.17802

Malaya 1941 - Rahmat, R. and Anuar, H. (2020). Patriots Publishing Sdn Bhd, Kuala Lumpur. Reviewed by Dazmin Daud

This book is presented as an easy and simple in Malay language about the Japanese occupation on Malaya in 1941. This is a book every military historian should have on his/her reference collection. The content of the book is also suitable for secondary school students and also for the first year undergraduate students in the Malaysia education institutions. It presents basic information on military logistics and strategies from Japanese and British perspectives. It is interesting to read line by line on how the Japanese army advanced from the Eastern and Northern parts of Malaya. At same time, readers can understand on how the British army executed defense and ambushed tactics in order to delay the movement of Japanese army towards Singapore. It is worth the RM28.00 price! First, it collects in one book, all the basic information on Japanese and British military jargons that you always wanted to know in the scope of World War II military history. Second, this is a thoroughly simple military history book with important dates and events the battles between Japanese and British armies from 1941 to 1942. Finally, there is useful information in this book that describes selected Japanese and British war planes and ships that had been used during the conflict.

Whilst much has been written on the Japanese occupation in World War II, very little attention has been written about the events that happened in 1941 in Malaya. During this period, there was a tireless effort from the British army to prevent further advancement of the Japanese army towards Singapore. Therefore, this book provides an overall view on how the Japanese strategically entered Malaya and how the British prepared a strategy to stop the invasion. The aim of this book is to reduce the gap in the Malay language about the Japanese occupation on Malaya.

The book is arranged in an introduction and 15 chapters. The introduction is about a brief story on Japanese army. During the Meiji era, the army was developed in systematic way in order to pace with other Western super-powers at that time. At the end of the introduction, the authors 


\section{MIMacrothink}

share Tables that provides information pertaining to the invasion time on Kota Bharu (Malaya) by the Japanese.

The chapters are (1) An overview of British army; (2) Japanese army under the Meiji era; (3) Brief information of Japanese army commanders in Malaya; (4) Brief information of British army commanders in Malaya; (5) Z Force and the sinking of HMS Prince of Wales and HMS Repulse; (6) Matador Operation; (7) Kroh Column; (8) Battle of Kota Bharu; (9) Battle of Jitra; (10) Battle of Kampar; (11) Battle of Slim River; (12) Battle of Gemas, Muar and Parit Sulong; (13) Battle of Endau; (14) Factors that attribute to the fall of Malaya to Japan; and (15) Weapon system. Besides the chapters above, the book also provides brief information about the authors, Mr. Rafe Rahmat and Mr. Hairil Anuar with interviews. The book ends with glossary and references.

The language and flow are not hard to learn when viewed in terms of the perspective of military history in Malaya during the World War II. More importantly, readers have a great deal to gain historical knowledge. While there are numerous fine history books on the subject of Japanese invasion during World War II, this book puts all the salient events during the period of 1941 in Malaya in one place. It is hope that in future, this book can be translated in to other languages for the benefits of non-Malay language readers. The reviewer congratulates the authors for this timely book. Figure1 shows the front page of the book.

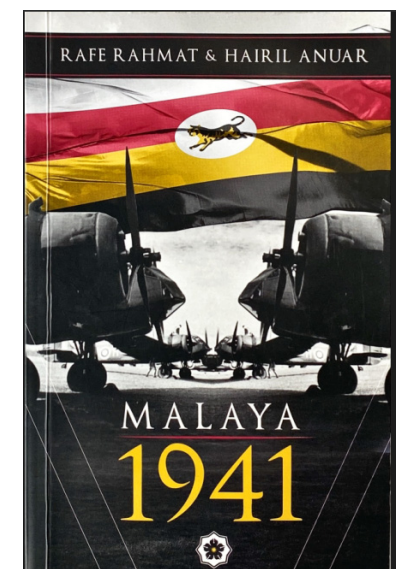

Below are the details of the book:

Title: Malaya 1941

Authors: Rafe Rahmat and Hairil Anuar

Year Published: 2020

Publisher: Patriots Publishing Sdn Bhd, Kuala Lumpur, Malaysia

Language: Malay

ISBN: 978-967-2437-04-8

Cover: Paperback

Number of Pages: 206 
The reviewer alone is responsible for the opinion expressed.

\section{Bibliography}

Rahmat, R., \& Anuar, H. (2020). Malaya 1941. Kuala Lumpur: Patriots Publishing Sdn Bhd.

\section{Copyright Disclaimer}

Copyright reserved by the author(s).

This article is an open-access article distributed under the terms and conditions of the Creative Commons Attribution license (http://creativecommons.org/licenses/by/3.0/). 